\title{
Effect of ground fenugreek seeds (Trigonella foenum-graecum) on feed consumption and milk performance in Anatolian water buffaloes
}

\author{
Taskin Degirmencioglu ${ }^{1}$, Halil Unal ${ }^{2}$, Selda Ozbilgin ${ }^{3}$, and Hasan Kuraloglu ${ }^{2}$ \\ ${ }^{1}$ Department of Feed Technology and Animal Nutrition, Karacabey Vocational School, \\ Uludag University, Bursa, 16059, Turkey \\ ${ }^{2}$ Department of Biosystems Engineering, Faculty of Agriculture, Uludag University, Bursa, 16059, Turkey \\ ${ }^{3}$ Department of Animal Health and Husbandry, Karacabey Vocational School, \\ Uludag University, Bursa, 16059, Turkey
}

Correspondence to: Taskin Degirmencioglu (taskin@uludag.edu.tr)

Received: 28 September 2015 - Revised: 8 July 2016 - Accepted: 12 July 2016 - Published: 2 August 2016

\begin{abstract}
In this study, the effects of a diet including fenugreek (Trigonella foenum-graecum) seed on feed consumption and milk performance were examined. A total of 24 buffaloes were randomly divided into two groups (12 animals each). The diet containing ground fenugreek seed (GFS) improved total dry matter (13.17$\left.14.00 \mathrm{~kg} \mathrm{day}^{-1}\right)(P<0.05)$ and daily concentrated feed consumption $\left(2.90-3.81 \mathrm{~kg} \mathrm{day}^{-1}\right)(P<0.01)$ and significantly increased milk production $\left(7.34-8.01 \mathrm{~kg} \mathrm{day}^{-1}\right)(P<0.01)$ in Anatolian water buffaloes (AWBs). In future work, the use of other herbs in AWB may be investigated.
\end{abstract}

\section{Introduction}

The water buffalo is the second-most important species in the world in terms of milk production, after dairy cows (Coroian et al., 2013). The productivity in other countries is lower due to the fact that only Italy has undertaken a great deal of work on recording, selection and genetic improvement, health, and on improving feeding and livestock systems. It has been reported that milk production during lactation periods of 270 days in Italy is $2220 \mathrm{~kg}$ with $8.4 \%$ fat and $4.6 \%$ protein (Borghese, 2013). While the milk yield of buffaloes in other countries, such as Turkey and Romania, is about $1247-1200 \mathrm{~kg}$; in Iran it is $1600 \mathrm{~kg}$ in 220 days of lactation (Borghese and Mazzi, 2005). They are mostly bred in the central Black Sea, Marmara (Thrace) and western Central Anatolia regions of Turkey (Atasever and Erdem, 2008). In comparison with buffaloes reared in village conditions, buffaloes under experimental conditions show more favourable values for mean lactation period ( 245 vs. 250 days), maximum and minimum milk yield (1.715 vs. 1.603 and 4.42 vs. $1.86 \mathrm{~L}$, respectively), and mean fat milk percentage $(8$ vs. $7 \%$ ) (Soysal et al., 2007). Anatolian water buffaloes
(AWBs) also hold an important place in Turkish food culture. A portion of the production of buffalo milk is used to meet the nutritional needs of local owners, and the rest is sold to the dairy sector to produce yogurt and kaymag (Degirmencioglu et al., 2015). The milk productivity of AWB is low because of traditional feeding based on pasturing. The milk supply can be increased by the use of certain herbs in cattle. Herbs such as fenugreek, alfalfa, soybean, lucerne, berseem, yucca, mahua and guar contain saponins (Yoshiki et al., 1998). Fenugreek (Trigonella foenum-graecum) is an annual crop belonging to the legume family (Acharya et al., 2006). The seeds of fenugreek contain alkaloids, flavonoids, saponins, amino acids, tannins and certain steroidal glycosides as well as proteins (Yadav et al., 2011). Saponins are naturally occurring surface-active glycosides. Chemically, saponins are high-molecular-weight glycosides in which sugars (glycone) (1-8 residues) are linked to a triterpene or steroidal aglycone moiety (Hostettmann and Marston, 1995). Johnson et al. (1986) found that some saponins increase the permeability of intestinal mucosal cells. Herbs containing saponin can contribute to meeting nutrient requirements, stimulate the endocrine system and affect intermediate nu- 
Table 1. Basic information on the examined buffaloes.

\begin{tabular}{lcccc}
\hline Groups & Number of Buffaloes & Body weight $(\mathrm{kg})$ & Days in milk & ${\text { Milk yield }\left(\mathrm{kg} \mathrm{day}^{-1}\right)}^{\text {(A) }}$ \\
\hline Groups 1 (A) & 12 & $521.50 \pm 5.50$ & $35.33 \pm 0.91$ & $4.37 \pm 0.18$ \\
Groups 2 (B) & 12 & $526.33 \pm 6.71$ & $37.92 \pm 1.94$ & $4.48 \pm 0.17$ \\
Significance level & & $\mathrm{NS}$ & $\mathrm{NS}$ & $\mathrm{NS}$ \\
\hline
\end{tabular}

NS: non-significant. Group average body condition score (BCS) is 2.5-3.

trient metabolism (Wang et al., 2000; Wenk, 2000). In addition, saponin-rich materials increase the partitioning of nutrients towards microbial mass, mainly by affecting protein degradation and through anti-protozoal effects (Goel et al., 2008). Kamel (2000) reported that fenugreek seed stimulates appetite. However, there is much more available information about herbs in relation to farm animals other than to buffaloes. The milk yield-increasing effect of fenugreek seeds has been investigated mainly in ruminants. Positive effects of fenugreek seeds on milk production in ruminants have been reported by El-Alamy et al. (2001), Abo El-Nor et al. (2007) and Balgees et al. (2013).

The objective of the present study was to investigate the effects of ground fenugreek seed (GFS) on feed consumption and milk performance in AWB.

\section{Materials and methods}

\subsection{Study site}

This research was conducted in Karaoglan Village, located in Mustafakemalpasa, in June.

\subsection{Animals, treatments and experimental design}

Buffaloes (5 and 6 years old) were selected primarily according their milk yield prior to the start of the experiment (Table 1). A total of 24 buffaloes were randomly divided into two groups (12 animals each). The experiment lasted for 30 days, during which the first 2 weeks were the preliminary period for adaptation, and data for statistical analysis were collected in the last 2 weeks. In group 1 and group 2 , the buffaloes were fed two different dietary treatments (designated A and B, respectively; DM basis; Table 2). The groups were milked twice a day by a milking machine. The treatment of grinding fenugreek seeds proceeded at $3 \mathrm{~mm}$ intervals. Diet A contained no GFS, and B diet contained $50.0 \mathrm{~g} \mathrm{GFS} \mathrm{kg}^{-1}$. The applied dosage of GFS was chosen based on the dosage used by Balgees et al. (2013). During the trial, all buffaloes were allowed ad libitum pasture and received corn silage $\left(22 \mathrm{~kg} \mathrm{day}^{-1}\right)$, alfalfa hay $\left(5 \mathrm{~kg} \mathrm{day}^{-1}\right)$ and $0.70 \mathrm{~kg}$ of the experimental diet (per $1.0 \mathrm{~kg}$ of milk per day) (A and B: 191.3 and $199.4 \mathrm{~g} \mathrm{CP} \mathrm{kg}^{-1} \mathrm{DM}$ and 2861 and $2888 \mathrm{ME}\left(\mathrm{kcal} \mathrm{kg} \mathrm{DM}^{-1}\right)$ ). The buffalo ration was formulated to correspond to $4.0 \mathrm{~kg} \mathrm{day}^{-1}$ of milk production with $7.0 \%$ fat and $5.0 \%$ protein in the lactation stage (3045 days), according to National Research Council (NRC) (2001) recommendations. For both groups, alfalfa was offered at 06:30 LT (local time, UTC +2), and silage was offered once a day 19:30 LT. The buffaloes had ad libitum access to water and pasture. Dry-matter intake was measured at the end of the sample collection period by weighing the offered diet and refusals from the previous day. Pasture consumption was not determined because of free pasturing.

\subsection{Chemical composition}

Ration samples were collected daily to determine DM consumption according to DM analysis of the feeds (at $105^{\circ} \mathrm{C}$ overnight). After drying, the samples were ground $(1 \mathrm{~mm})$ for chemical analysis. The feeds were evaluated to determine crude protein according to the AOAC (1990) and fibre fractions (NDF and ADF) (Robertson and Van Soest, 1981). The metabolisable energy value of the feeds was calculated based on chemical analyses using computer software from the National Research Council (NRC) (2001). The solidsnot-fat content (SNF) and fat and protein components of the milk were analysed using a Milcosan FT-120 device. SCC was determined with a Somacount150 (Bentley Instruments, Chaska, USA).

\subsection{Machine milking of Anatolian water buffaloes}

In this study, a semi-stable type of bucket milking machine was used. The capacity of the mechanical vacuum pumps was $200 \mathrm{~L} \mathrm{~min}^{-1}(50 \mathrm{kPa})$. The milking machine was capable of milking two animals at the same time. Mechanical pneumatic pulsators were used on the machine. The milking bucket capacity was $20 \mathrm{~L}$. There was a pneumatic pulsator milking into each bucket. Pulsation was operated a pulse rate of $60 / 40$. Thus, this study is based on the nutrition of GFS in AWB, using a single vacuum and pulse adjusted on the machine. Therefore, an electronic pulse-measuring device (Exendis, PT-V Pulsatortester) and pressure-measuring device (PT 100 vacuum meter) were used, with the vacuum milking machine working at a pressure of $45 \mathrm{kPa}$ and a pulse rate of 60 pulses $\mathrm{min}^{-1}$; all milking experiments were carried out in this way with the same levels being set. Milk yields were measured with a portable mechanical milk meter mounted to the milking line (Tru-Test, $33 \mathrm{~kg}$ capacity). 
Table 2. Composition of the feed mixtures and roughage fed to the experimental buffaloes.

\begin{tabular}{|c|c|c|c|c|c|}
\hline \multirow[t]{2}{*}{ Compound $\left(\mathrm{g} \mathrm{kg}^{-1}\right)$} & \multicolumn{2}{|c|}{ Diet } & \multicolumn{3}{|c|}{ Roughages } \\
\hline & A: $0 \mathrm{~g} \mathrm{GFS} \mathrm{kg}^{-1}$ & B: $50 \mathrm{~g} \mathrm{GFS} \mathrm{kg}^{-1}$ & Alfalfa hay & Corn silage & Barley hay \\
\hline Barley & 310 & 310 & & & \\
\hline Wheat & 320 & 320 & & & \\
\hline Sunflower meal & 350 & 300 & & & \\
\hline Fenugreek & - & 50 & & & \\
\hline Marble powder & 10 & 10 & & & \\
\hline Salt & 7.5 & 7.5 & & & \\
\hline Vitamin + minerals $*$ & 2.5 & 2.5 & & & \\
\hline Total & 1000 & 1000 & & & \\
\hline \multicolumn{6}{|c|}{ Nutrient composition $\left(\mathrm{g} \mathrm{kg}^{-1}\right)$} \\
\hline $\mathrm{DM}$ & 887 & 889 & 904.8 & 342.3 & 933.1 \\
\hline OM & 855.7 & 854.4 & 815.5 & 288 & 869.1 \\
\hline $\mathrm{CP}$ & 191.3 & 199.4 & 133.0 & 73.1 & 28.3 \\
\hline $\mathrm{EE}$ & 19.5 & 20.8 & 15.5 & 25.6 & 10.5 \\
\hline CELL & 90.2 & 116.2 & 334.6 & 209.7 & 405.5 \\
\hline $\mathrm{CA}$ & 31.3 & 34.6 & 89.3 & 54.3 & 64.0 \\
\hline NFE & 554.7 & 518 & 332.4 & - & 424.8 \\
\hline Starch & 416.3 & 321.7 & 21.8 & 240.6 & 6.8 \\
\hline $\mathrm{NDF}$ & 192.0 & 235.7 & 509.9 & 472.8 & 741.0 \\
\hline $\mathrm{ADF}$ & 136.7 & 191.4 & 463.9 & 338.9 & 604.1 \\
\hline $\mathrm{ADL}$ & 36.8 & 52.2 & 113.5 & 69.7 & 109.0 \\
\hline $\operatorname{ME}\left(\mathrm{kcal} \mathrm{kg}^{-1}\right)$ & 2861 & 2888 & 1801 & 769.7 & 1650 \\
\hline
\end{tabular}

* Trace minerals and vitamins (per kg): $50000 \mathrm{mg}$ niacin; $150 \mathrm{mg} \mathrm{Co} ; 800 \mathrm{mg}$ iodine; $150 \mathrm{mg} \mathrm{Se} ; 50000 \mathrm{mg} \mathrm{Mn} ; 50000 \mathrm{mg} \mathrm{Fe} ; \mathrm{Zn}$ $50000 \mathrm{mg} ;$ Cu $10000 \mathrm{mg} ; 15000000$ IU vitamin A; 3000000 IU vitamin D3; $20000 \mathrm{mg}$ vitamin E. DM: dry matter; OM: organic matter; CP: crude protein; EE: ether extract; CELL: cellulose; CA: crude ash; NFE: nitrogen-free extract; NDF: neutral detergent fibre; ADF: acid detergent fibre; ADL: acid detergent lignin; ME: metabolisable energy.

Table 3. Chemical composition of fenugreek seeds on a DM basis (\%).

\begin{tabular}{rrrrrrrrrrr}
\hline DM & OM & CP & EE & CE & CA & NFE & ADF & NDF & ADL & ME $\left(\mathrm{kcal} \mathrm{kg}^{-1}\right)$ \\
\hline 91.11 & 87.88 & 29.49 & 3.86 & 6.20 & 3.23 & 48.33 & 11.50 & 14.44 & 2.61 & 2373.67 \\
\hline
\end{tabular}

DM: dry matter; OM: organic matter; CP: crude protein; EE: ether extract; CE: cellulose; CA: crude ash; NFE: nitrogen-free extract; ADF: acid detergent fibre; NDF: neutral detergent fibre; ADL: acid detergent lignin; ME: metabolizable energy calculated according to the equation of Lodhi et al. (1976).

\subsection{Statistical analysis}

An analysis of variance was conducted using the SPSS version 15.0 statistical package (2006), and means were compared using the $t$ test models described by Cochran and Cox (1957):

$Y_{i j k}=\mu+a_{i}+b_{j}+e_{i j k}$,

where $Y_{i j k}$ is observations; $\mu$ is the population mean; $a_{i}$ is the group effect (1: GFS kg-1, and 2: $\left.50 \mathrm{~g} \mathrm{GFS} \mathrm{kg}^{-1}\right) ; b_{j}$ is the animals $(j=1,2,3, \ldots, 23$ or 24$)$, and $e_{i j k}$ is the effect of accidental error and random environmental factors.

The chemical composition of fenugreek seed is presented in Table 3.

\section{Results and discussion}

\subsection{The effects of fenugreek seeds}

During the experimental period, silage DM consumption in groups 1 and 2 was 5.72 and $5.11 \mathrm{~kg} \mathrm{day}^{-1}$, respectively $(P<0.05$; Table 4$)$. Alfalfa DM consumption in these groups was 4.46 and $5.08 \mathrm{~kg} \mathrm{day}^{-1}$, respectively $(P<0.05)$. Total DM consumption in group 2 was higher than in the control group 1 (5.92\% $(P<0.05)$; Table 4$)$. These findings were consistent with the results of Abo El-Nor et al. (2007), showing that increase in dry-matter intake was associated with the addition of fenugreek seeds $\left(0.2 \mathrm{~kg} \mathrm{day}^{-1}\right)$ in buffaloes $(5.79 \%(P<0.05))$. Similarly Balgees et al. (2013) reported that Nubian goats fed diets containing 5, 10 and $15 \%$ fenugreek seeds exhibited increases of approximately 
Table 4. The effects of fenugreek seeds on DM intake and the milk yield and composition (mean $\pm \mathrm{SE}$ ).

\begin{tabular}{|c|c|c|c|}
\hline \multirow[t]{2}{*}{ Parameter } & \multicolumn{2}{|c|}{ Groups } & \multirow{2}{*}{$\begin{array}{l}\text { Significance } \\
\text { level }\end{array}$} \\
\hline & (Control) Group 1 & (GFS) Group 2 & \\
\hline Silage DM intake $\left(\mathrm{kg} \mathrm{day}^{-1}\right)$ & $5.72 \pm 0.29$ & $5.11 \pm 0.11$ & $*$ \\
\hline Alfalfa DM intake $\left(\mathrm{kg} \mathrm{day}^{-1}\right)$ & $4.46 \pm 0.29$ & $5.08 \pm 0.15$ & $*$ \\
\hline Barley straw DM intake & $0.08 \pm 0.02$ & $0.00 \pm 0.00$ & $* *$ \\
\hline Concentrate DM intake & $2.90 \pm 0.23$ & $3.81 \pm 0.17$ & $* *$ \\
\hline Total DM intake ${ }^{1}$ & $13.17 \pm 0.41$ & $14.00 \pm 0.34$ & $*$ \\
\hline Milk yield $\left(\mathrm{kg} \mathrm{day}^{-1}\right)$ & $7.34 \pm 0.24$ & $8.01 \pm 0.19$ & $* *$ \\
\hline $4 \%$ FCM $\left(\mathrm{kg} \mathrm{day}^{-1}\right)^{2}$ & $9.31 \pm 0.34$ & $10.46 \pm 0.25$ & $* *$ \\
\hline Fat $(\%)$ & $5.80 \pm 0.19$ & $6.06 \pm 0.17$ & NS \\
\hline $\mathrm{SNF}(\%)$ & $10.18 \pm 0.05$ & $10.30 \pm 0.04$ & NS \\
\hline Protein $(\%)$ & $4.95 \pm 0.15$ & $5.11 \pm 0.21$ & NS \\
\hline $\operatorname{SCC}\left(\times \log 10 \mathrm{~mL}^{-1}\right)$ & $60.35 \pm 6.83$ & $53.70 \pm 7.57$ & NS \\
\hline
\end{tabular}

49.57, 55.65 and $58.56 \%$ in their feed intake. Petit et al. (1993) concluded that fenugreek seeds (FS) increased feed consumption in rats. The positive effects of FS on DM consumption might be explained by an effect on the hypothalamus resulting in stimulation of hunger centres in the brain and increasing the desire to eat (Petit et al., 1993). In the present study, the daily milk yields for buffaloes fed diets $\mathrm{A}$ and $\mathrm{B}$ were 4.37 and $4.48 \mathrm{~kg} \mathrm{day}^{-1}$, respectively, at the beginning of the study $(P>0.05)$. Mean daily milk production was higher $(P<0.01)$ in animals fed the diet containing GFS compared with the control diet (7.34-8.01 $\left.\mathrm{kg} \mathrm{day}^{-1}\right)$ at the end of the experiment. The differences between the mean milk production values of group 1 and group 2 were significant $(P<0.05$; Table 4$)$. These results were similar to those reported previously (El-Alamy et al., 2001; Balgees et al., 2013). Abo El-Nor et al. (2007) also observed a significant increase in milk production, of $1.48 \mathrm{~kg} \mathrm{day}^{-1}$, in early lactating dairy buffaloes supplemented with FS, but the ration included $0.20 \mathrm{~kg}$ of FS concentrate (DM basis). In the present study, the increase in milk production determined in group 2 was $0.67 \mathrm{~kg} \mathrm{day}^{-1}$ (Table 4). This value was significantly lower than the value of $1.48 \mathrm{~kg} \mathrm{day}^{-1}$ reported by Abo ElNor et al. (2007). The ration contained $5 \%$ GFS as feed (\% on DM basis). It was decided that the lowest dosage would be used in the diet to prevent any unpleasant smell from being transferred to the milk, in addition to the economic cost. This effect observed in group 2 may be due to diosgenin, which is a chemical compound in fenugreek seeds similar to the hormone oestrogen stimulating an increase in milk flow (Tiran, 2003). A similar trend was recorded for $4.0 \%$ FCM. The yield of $4.0 \%$ FCM was increased by $10.99 \%$ under FS feeding (9.31 vs. $10.46 \mathrm{~kg} \mathrm{day}^{-1}$ for group 1 and group 2, respectively; $P<0.01$; Table 4). The $5 \%$ GFS treatment had no significant effect on the percentages of SNF, protein or
SCC in milk. This result was similar to the result obtained by Abo El-Nor et al. (2007), who found that there was an insignificant effect on milk fat. However, Balgees et al. (2013) reported that in Nubian goats, the milk fat content was reduced in groups given 10 and $15 \%$ FS compared with groups given 0 and $5 \%$ FS. The decrease in the milk fat content might be due to increasing the milk yield between groups.

\section{Conclusions}

The results of the present study show that feeding GFS to early lactating AWB resulted in a significant increase in milk production of $0.67 \mathrm{~kg} \mathrm{day}^{-1}$. This study demonstrated the positive effects of GFS on the performance of buffaloes early in lactation under village conditions. Therefore, the use of diet B, containing GFS, can be offered as an alternative method of enhancing milk production on AWB farms. In future work, the use of other herbs in AWB may be investigated.

Edited by: M. Mielenz

Reviewed by: M. Sincik, O. Kacar, and one anonymous referee 


\section{References}

Abo El-Nor, S. A. H., Khattab, H. M., Al-Alamy, H. A., Salem, F. A., and Abdou, M. M.: Effect of some medicinal plants seeds in the rations on the productive performance of lactating buffaloes, Int. J. Dairy Sci., 2, 348-355, 2007.

Acharya, S., Srichamroen, A., Basu, S., Ooraikul, B., and Basu, T.: Improvement in the nutraceutical properties of fenugreek (Trigonella foenum graecum L.), Songklanakarin J. Sci. Technol., 28, 1-9, 2006.

AOAC: Official methods of analysis, 15th Edn. Assoc. Off. Anal Chem., Arlington, VA, 1990.

Atasever, S. and Erdem, H.: Water buffalo raising and its future in Turkey, Ondokuz Mayıs University, J. Agric. Faculty, 23, 59-64, 2008 (in Turkish).

Balgees, A., Atta Elmnan Nuha, M., Jame, S. A., Rahmatalla, E. O.,Amasiab, A., and Mahala, G.: Effect of fenugreek (Ttrigonella foenum graecum) seeds supplementation on feed intake, some metabolic hormones profile, milk yield and composition of nubian goats, Res. J. Anim. Sci., 7, 1-5, 2013.

Borghese, A.: Buffalo livestock and products in Europe, Buffalo Bulletin, 32, 50-74, 2013.

Borghese A. and Mazzi M.: Buffalo Population and Strategies in the World, Chapter 1, Buffalo Production and Research, Fao Regional Office For Europe 17 pp., 2005.

Cochran, W. G. and Cox, G. M.: In Experimental Designs, 2nd Edn., John Wiley and Sons, New York, NY, 536 pp., 1957.

Coroian, A., Erler, S., Matea, C. T., Miresan, V., Raducu, C., Bele, C., and Coroian, C. O.: Seasonal changes of buffalo colostrum: physicochemical parameters, fatty acids and cholesterol variation, Chem. Cent. J., 7, 2-9, 2013.

Degirmencioglu, T., Unal, H., and Kuraloglu, H.: Comparison of extensive or semi-intensive feeding for Anatolian water buffalo, Emirat. J. Food Agric., 27, 712-715, 2015.

EL-Alamy, H. A., Kattab, H. M., El Nor, S. A., Salam, F. A. F., and Abduo, M. M. A.: Milk production response to supplementing rations with some medical herbs of lactating buffalo, Proceedings of the 8th Egyptian Conference for Dairy Science and Technology, Cairo, 3-5 November 2001, 675-686, 2001.

Goel, G., Makkar, P. S. H., and Becker, K.: Effects of Sesbania sesban and Carduus pycnocephalus leaves and Fenugreek (Trigonella foenum-graecum L.) seeds and their extracts on partitioning of nutrients from roughage- and concentrate-based feeds to methane, Anim. Feed Sci. Tech., 147, 72-89, 2008.
Hostettmann, K. and Marston, A.: Saponins, Cambridge: Cambridge University Press, 1995.

Johnson, I. T., Gee, J. M., Price, K., Curl, C., and Fenwick, G. R.: Influence of saponins on gut permeability and active nutrient transport in vitro, J. Nutri., 116, 2270-2277, 1986.

Kamel, C.: A novel look at a classic approach of plant extracts, Feed Mix, 8, 16-18, 2000.

Lodhi, G. N., Singh, D., and Ichponani, J. S.: Variation in nutrient content of feed stuffs rich in protein and reassessment of the chemical methods for metabolizable energy estimation for poultry, J. Agric. Sci. Camb., 86, 293-303, 1976.

NRC: Nutrient requirements of dairy cattle, National Academy Press, Washington, 341-353, 2001.

Petit, P., Sauvaire, Y., Ponsin, G., Manteghetti, M., Fave, A., and Ribes, G.: Effects of a fenugreek seed extract on feeding behaviour in the rat: Metabolic endocrine correlates, Pharmacol. Biochem. Behav., 45, 369-374, 1993.

Robertson, J. B. and Van Soest, P. J.: The detergent system of analysis and its application to human foods, in: The Analysis of Dietary fiber in food, edited by: James, W. P. T. and Theander, O., Marcel Dekker, New York, 123 pp., 1981.

Soysal, M. I., Tuna, Y. T., Gurcan, E. K., Ozkan, E. , Kok, S., Castellano, N., Cobanoglu, O., and Barone, C. M. A.: Anatolian water buffaloes husbandry in Turkey: preliminary results on somatic characterization, Ital. J. Anim. Sci., 6, 1302-1307, 2007.

SPSS.: Statistical Package for Social Sciences, Pc Version 15, SPSS Inc. 444 N, Michigan Avenue Chicago, USA, 2006.

Tiran, D.: The use of fenugreek for breast feeding women, Complement Ther. Nurs. Midwifery, 9, 155-156, 2003.

Yadav, R., Tiwari, R., Chowdhary, P., and Pradhan, C. K.: A pharmacognostical monograph of trigonella foenum- graecum seeds, Int. J. Pharm. Pharm. Sci., 3, 442-445, 2011.

Yoshiki, Y., Kudou, S., and Okubo, K.: Relationship between chemical structures and biological activities of triterpenoidsaponins from soybean (Review), Biosci. Biotech. Biochem., 62, 22912299, 1998.

Wang, Y., McAllister, T. A., Yanke, L. J., and Cheeke, P. R.: Effect of steroidal Saponin from Yucca schidigeraextract on ruminal microbes, J. App. Microbiol., 88, 887-896, 2000.

Wenk, C.: Why all discussion about herbs? Biotechn. In the Feed Industry, Proc. Alltech's 16th Annu. Symp. Alltech Technical Publications, Nottginham Univ. Press. Nicholasvile, KY, 79-96, 2000. 